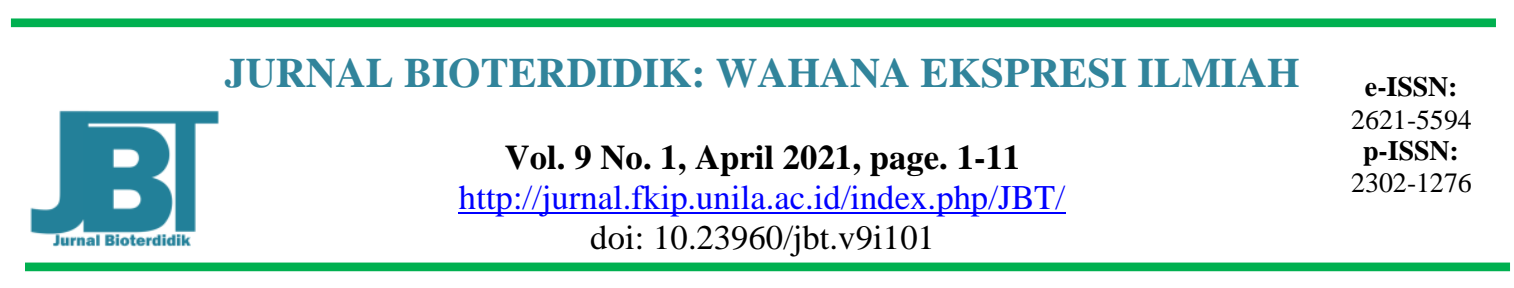

\title{
Mengukur Keterampilan Diskusi Tertulis di Media Sosial (Whatsapp) Menggunakan Rubrik Penilaian Diskusi
}

\author{
Pramudiyanti* \\ Pendidikan Biologi, Fakultas Keguruan dan Ilmu Pendidikan, Universitas Lampung, Jl. Prof. Dr. \\ Soemantri Brojonegoro No. 1 Bandar Lampung, Indonesia \\ *e-mail: pramu.diyanti@ fkip.unila.ac.id
}

Abstract: Measuring Written Discussion Skills Using a Discussion Assessment Rubric Using Whatsapp Social Media. The research objective was to explain the use of a written discussion skills assessment rubric on Whatsapp social media. This research is a qualitative descriptive study using literature review and survey methods. Respondents consisted of teaching staff in the Biology Education Study program. Data obtained using a questionnaire and google search application. The results obtained are 18 literatures regarding discussion as a learning method and as a skill, there are 4 articles that suggest face-to-face discussion assessment rubrics. The use of written discussion rubrics, namely 1) makes it easy for teachers to assess student learning activities; 2) provide directions for teachers to practice written discussion skills for students; and 3) provide an overview of the students' discussion skills.

Keywords: written discussion skills, written discussion, whatsapp, written discussion assessment rubric

\begin{abstract}
Abstrak: Mengukur Keterampilan Diskusi Tertulis Menggunakan Rubrik Penilaian Diskusi Menggunakan Media Sosial Whatsapp. Tujuan penelitian adalah menjelaskan penggunaan rubrik penilaian keterampilan diskusi tertulis pada media sosial Whatsapp. Penelitian ini adalah penelitian deskriptif kualitatif dengan metode kajian pustaka dan survei. Responden terdiri dari staf pengajar program Studi Pendidikan Biologi. Data diperoleh menggunakan kuesioner dan aplikasi google search. Hasil yang diperoleh yakni terdapat 18 literatur mengenai diskusi sebagai metode pembelajaran dan sebagai keterampilan, terdapat 4 artikel yang mengemukakan mengenai rubrik penilaian diskusi tatap muka. Penggunaan rubrik diskusi tertulis yakni 1) memberikan kemudahan kepada pengajar memberikan penilaian aktivitas belajar mahasiswa; 2) memberikan arah bagi pengajar untuk melatih keterampilan diskusi tertulis bagi mahasiswa; dan 3) memberikan gambaran keterampilan diskusi yang dimiliki oleh mahasiswa.
\end{abstract}

Kata kunci: keterampilan diskusi tertulis, written discussion, whatsapp, rubrik penilaian diskusi tertulis 


\section{PENDAHULUAN}

Pendidikan tahun 2020 hingga kini merupakan pendidikan adaptif bagi semua civitas akademik baik di kampus maupun sekolah. Pendidikan adaptif ini adalah bentuk respon terhadap wabah pandemi Covid-19. Salah satu respon bidang pendidikan berupa pemberian pembelajaran daring bagi para mahasiswa. Kemendikbud telah menerbitkan peraturan pembelajaran dalam kondisi khusus, di antaranya mengenai pelaksanaan pembelajaran dengan cara kontekstual dan bermakna menggunakan berbagai strategi yang sesuai dengan kebutuhan dan kondisi peserta didik, satuan pendidikan, dan daerah serta memenuhi prinsip pembelajaran (Kemendikbud, 2020)

Beberapa hasil penelitian mengenai pembelajaran online selama pandemi menyebutkan bahwa meskipun ada peningkatan pengetahuan dan keterampilan pesert didik, namun guru merasakan kurang maksimal dalam pelaksanaan pemberian materi yang dapat dipahami oleh siswa (Waruwu, 2020). Hasil ini dilaporkan pula oleh Cintiasih (2020) bahwa 45-50\% siswa antusias dan mampu memahami materi, selebihnya tidak antusias dan tidak mampu memahami materi pembelajaran.

Pelaksanaan pembelajaran pada kondisi khusus berpedoman pada 8 prinsip. Prinsip ketujuh yaitu pelaksanaan pembelajaran fokus pada penguasaan kompetensi, berpusat pada peserta didik (student-centered learning) untuk membangun kepercayaan diri dan keberhargaan diri. Prinsip ini dimplementasikan dalam proses pembelajaran setiap pertemuan. Metode pembelajaran yang dapat digunakan yakni metode diskusi. Diskusi merupakan metode yang melibatkan interaksi semua pihak dalam proses pembelajaran. Saat ini telah lazim digunakan metode diskusi online pada berbagai wahan aplikasi komunikasi. Diskusi online merupakan suatu cara pembelajaran mengenai suatu masalah yang berbasis website. Berdiskusi dapat melibatkan peserta didik memberikan saran atau gagasan (Yuberti, 2015).

Pelaksanaan metode diskusi sebagai sarana meningkatkan kompetensi siswa membutuhkan suatu pedoman penilaian. Penilaian bermanfaat bagi pengajar dan mahasiswa guna memperoleh umpan balik untuk perbaikan proses dan juga kompetensi mahasiswa (Kemendikbud, 2020). Selain itu penilaian kompetensi siswa yang menggunakan metode diskusi online masih belum banyak dtemukan. Oleh itu perlu dikaji bagaimana melakukan penilaian diskusi sebagai kompetensi mahasiswa. Kompetensi dapat diturunkan ke dalam istilah operasional yakni, penguasaan konsep, lugas berbicara, berbahasa yang benar, dan menghargai diri sendiri dan orang lain dalam berpendapat.

Tujuan penulisan makalah adalah menjelaskan penggunaan rubrik penilaian keterampilan diskusi tertulis pada media sosial Whatsapp. Rubrik penilaian dirujuk dari Pramudiyanti (2020). Rubrik ini menjelaskan mengenai penilaian diskusi sebagai sebuah capaian pembelajaran sekaligus sebagai alat untuk memperoleh umpan balik proses pembelajaran.

\section{METODE}

Metode penulisan artikel ini menggunakan metode kajian pustaka dan survei. Penelitian dilakukan pada bulan Januari di Universitas Lampung, Program Studi Pendidikan Biologi. Data pada penelitian ini bersifat kualitatif berupa 1) penjelasan dari responden mengenai pembelajaran daring dan 2) kajian pustaka terdiri dua sumber yaitu, menggunakan artikel utama berjudul Learning writing discussion skills via whatsapp using structured and unstructured discussion technique dan artikel lain yang terkait dengan metode diskusi. Adapun responden yang dijadikan rujukan adalah para pengajar di program studi Pendidikan Biologi berjumlah 12 orang. 
Instrumen yang digunakan adalah kuesioner dan aplikasi google scholar. Teknik pengumpulan data dilakukan dengan menggunakan aplikasi google form dibagikan kepada responden (link kuesioner: https://forms.gle/inoAmcGFUow5YyLcA. Instrumen artikel utama terdiri dari tabel rubrik penilaian keterampilan diskusi. Selain itu artikel yang diperoleh dari aplikasi google scholar terdiri dari artikel ilmiah yang terkait dengan metode dan pengukuran keterampilan diskusi.

Teknik Analisis Data pada penelitian ini adalah mendeskripsikan hasil-hasil kueisoner dan kajian pustaka sepanjang memperjelas pengukuran keterampilan diskusi online.

\section{HASIL DAN PEMBAHASAN}

Hasil penelusuran pustaka diperoleh data yang disajikan pada Tabel 1. Penelitian yang telah dilakukan mengenai Metode Diskusi ada 11 Judul. Hasil ini terdiri dari penelitian pengembangan metode diskusi 2 buah, penelitian eksperimen 7 buah, dan Penelitian deskriptif non eksperimen 2 buah.

Tabel 1. Tangkapan Layar Menggunakan Kata Kunci Metode Diskusi

\begin{tabular}{|c|c|c|c|c|}
\hline No & Judul (Penulis) & Sumber & $\begin{array}{l}\text { Metode } \\
\text { Belajar }\end{array}$ & $\begin{array}{c}\text { Capaian } \\
\text { Pembelajaran }\end{array}$ \\
\hline 1 & $\begin{array}{l}\text { Pengembangan Forum Diskusi } \\
\text { Kuliah Online Mahasiswa } \\
\text { Pendidikan Fisika Universitas } \\
\text { Negeri Semarang. } \\
\text { (Ida Sudarwati) }\end{array}$ & $\begin{array}{l}\text { Skripsi. Program Studi } \\
\text { Pendidikan Fisika. } \\
\text { Universitas Negeri } \\
\text { Semarang. } 2017 .\end{array}$ & $\mathrm{Ya}$ & Bukan \\
\hline 2 & $\begin{array}{l}\text { Online Group Discussion Pada } \\
\text { Mata Kuliah Teknologi } \\
\text { Pembelajaran Fisika. } \\
\text { (Yuberti) }\end{array}$ & $\begin{array}{l}\text { Jurnal Ilmiah } \\
\text { Pendidikan Fisika Al- } \\
\text { Biruni Vol. } 04 \text { No. } 2 \\
\text { tahun 2015. }\end{array}$ & $\mathrm{Ya}$ & Bukan \\
\hline 3 & $\begin{array}{l}\text { Penggunaan Metode Diskusi } \\
\text { Kelompok pada Mata Pelajaran } \\
\text { Matematika dan PKn untuk } \\
\text { Meningkatkan Hasil Belajar } \\
\text { Siswa Kelas V SDN 006 Koto } \\
\text { Inuman Kecamatan Inuman. } \\
\text { (Aguswandi) }\end{array}$ & $\begin{array}{l}\text { Jurnal PAJAR PGSD } \\
\text { FKIP Universitas Riau. } \\
\text { Vol. } 1 \text { No 1 Januari } \\
2018 .\end{array}$ & $\mathrm{Ya}$ & Bukan \\
\hline 4 & $\begin{array}{l}\text { Perancangan Forum Diskusi } \\
\text { Mobile Online Learning. } \\
\text { (Agus Putranto) }\end{array}$ & $\begin{array}{l}\text { Comtech. } \\
\text { Vol.3 No.2 Desember } \\
\text { 2012: } 860-871 .\end{array}$ & Ya & Bukan \\
\hline 5 & $\begin{array}{l}\text { Efektifitas Metode Diskusi dalam } \\
\text { Pembelajaran Pendidikan Agama } \\
\text { Islam di SMPN } 6 \text { Banda Aceh. } \\
\text { (Muhammad Kautsar) }\end{array}$ & $\begin{array}{l}\text { Skripsi. Universitas } \\
\text { Negeri Islam Ar-raniry } \\
\text { Banda Aceh. }\end{array}$ & Ya & Bukan \\
\hline 6 & $\begin{array}{l}\text { Forum Diskusi Online (Ontell) } \\
\text { Sebagai Wahana Pembelajaran } \\
\text { Bahasa Inggris: Sebuah Analisis } \\
\text { Konten } \\
\text { (Urai Salam) }\end{array}$ & $\begin{array}{l}\text { Vol 9, No } 3(2012) \\
\text { Jurnal Visi Ilmu } \\
\text { Pendidikan }\end{array}$ & $\mathrm{Ya}$ & Bukan \\
\hline 7 & $\begin{array}{l}\text { Pengaruh Penggunaan Metode } \\
\text { Diskusi Tipe Buzz Group } \\
\text { Terhadap Prestasi Belajar Biologi } \\
\text { Peserta Didik Kelas X Mia 1 Sma } \\
\text { Negeri 1 Majene (Nurmiati dan } \\
\text { Irmadani) }\end{array}$ & $\begin{array}{l}\text { vol } 7 \text { No } 2 \text { (2017): } \\
\text { Jurnal Pendidikan Mipa } \\
\text { Lppm Stkip Taman } \\
\text { Siswa Bima } \\
\text { - Ntb }\end{array}$ & Ya & Bukan \\
\hline
\end{tabular}




\begin{tabular}{|c|c|c|c|c|}
\hline 8 & $\begin{array}{l}\text { Pengaruh Metode Diskusi } \\
\text { Dengan Model Pembelajaran Dd- } \\
\text { Ct (Deep Dialogue-Critical } \\
\text { Thinking) Dengan Pemberian } \\
\text { Penguatan Terhadap Prestasi } \\
\text { Belajar Akuntansi Pada Siswa } \\
\text { Kelas Xi Akuntansi Smkn } 1 \\
\text { Geger Madiun } \\
\text { (Alfi Qurrota A'yuni, Satrijo } \\
\text { Budiwibowo) }\end{array}$ & $\begin{array}{l}\text { Jurnal Akuntansi Dan } \\
\text { Pendidikan } \\
\text { Vol 3, No } 2 \text { (2014 }\end{array}$ & $\mathrm{Ya}$ & Bukan \\
\hline 9 & $\begin{array}{l}\text { Peningkatan Hasil Belajar } \\
\text { Menggunakan Pakem Dengan } \\
\text { Metode Diskusi Pada } \\
\text { Pembelajaran Fisika Dasar Pokok } \\
\text { Bahasan Mekanika } \\
\text { (Albert Lumbu, Indah Slamet } \\
\text { Budiarti) }\end{array}$ & $\begin{array}{l}\text { Jurnal Pendidikan Fisika } \\
\text { Dan Keilmuan By } \\
\text { Http://E- } \\
\text { Journal.Unipma.Ac.Id/I } \\
\underline{\text { ndex.Php/Jpfk/Index Is }} \\
\text { Vol 1, No 1 (2015) }\end{array}$ & $\mathrm{Ya}$ & Bukan \\
\hline 10 & $\begin{array}{l}\text { Penerapan Metode Diskusi- } \\
\text { Presentasi Dipadu Analisis Kritis } \\
\text { Artikel melalui Lesson Study } \\
\text { untuk Meningkatkan Pemahaman } \\
\text { Konsep, Kemampuan Berpikir } \\
\text { Kritis, dan Komunikasi. } \\
\text { (Zuni Mitasari, Nugroho Aji } \\
\text { Prasetiyo) }\end{array}$ & $\begin{array}{l}\text { Jurnal Bioedukatika } \\
\text { Issn 2338-6630 (Print) } \\
\text { | Issn 2541-5646 } \\
\text { (Online) } \\
\text { Department Of Biology } \\
\text { Education } \\
\text { Universitas Ahmad } \\
\text { Dahlan } \\
\text { Vol 4, No } 1(2016) \\
\end{array}$ & $\mathrm{Ya}$ & Bukan \\
\hline 11 & $\begin{array}{l}\text { Studi Komparasi antara Metode } \\
\text { Diskusi dengan Metode Role } \\
\text { Playing ditinjau dari Kreativitas } \\
\text { Siswa pada Pembelajaran PKn } \\
\text { Kelas VII SMPN 16Surakarta } \\
\text { Tahun Ajaran 2008/2009. } \\
\text { (Agustin Wulan Sari). }\end{array}$ & $\begin{array}{l}\text { Skripsi. Program Studi } \\
\text { Pendidikan } \\
\text { Kewarganegaraan. } \\
\text { Universitas Sebelas } \\
\text { Maret. Surakarta. }\end{array}$ & $\mathrm{Ya}$ & Bukan \\
\hline
\end{tabular}

Hasil pada Tabel 1 menyiratkan bahwa metode Diskusi merupakan salah satu metode yang digunakan dalam pembelajaran dari waktu ke waktu, pada kasus ini dari tahun 2009 hingga tahun 2018. Data ini masih bertambah yakni berdasarkan hasil survei online yang dilakukan pada Januari 2020, dan tertera pada Tabel 2.

Tabel 2. Penggunaan Metode Diskusi Tahun Akademik 2020/2021 Program Studi Pendidikan Biologi Unila

\begin{tabular}{|c|c|c|c|}
\hline No & Mata Kuliah & $\begin{array}{c}\text { Metode } \\
\text { Pembelajaran }\end{array}$ & Wahana Aplikasi Pembelajaran \\
\hline 1 & Teori Evolusi & Diskusi & \multirow{4}{*}{ Google meet } \\
\hline 2 & Desain Pembelajaran & Selainnya & \\
\hline 3 & Evaluasi Pembelajaran & Selainnya & \\
\hline 4 & Strategi Pembelajaran & Selainnya & \\
\hline 5 & Biologi Dasar & Diskusi & \multirow[t]{4}{*}{ Vclass Unila } \\
\hline 6 & Produksi dan Pemanfaatan Media Pembelajaran & Diskusi & \\
\hline 7 & Genetika & Selainnya & \\
\hline 8 & Zoologi & Selainnya & \\
\hline 9 & Biokimia & Selainnya & \multirow{2}{*}{$\begin{array}{l}\text { VClass } \\
\text { Whatsapp }\end{array}$} \\
\hline 10 & Ilmu Gizi dan Kesehatan & Diskusi & \\
\hline
\end{tabular}




\begin{tabular}{|c|c|c|c|}
\hline No & Mata Kuliah & $\begin{array}{c}\text { Metode } \\
\text { Pembelajaran }\end{array}$ & Wahana Aplikasi Pembelajaran \\
\hline 11 & Biologi Tanaman Obat & Selainnya & \\
\hline 12 & Biologi Konservasi & Diskusi & \\
\hline 13 & Botani Tumbuhan Tinggi & Diskusi & $\begin{array}{l}\text { VClass } \\
\text { Zoom meeting }\end{array}$ \\
\hline 14 & Biologi Dasar & Diskusi & \multirow[t]{3}{*}{ Vclass } \\
\hline 15 & Struktur Hewan & Diskusi & \\
\hline 16 & Perkembangan Hewan & Diskusi & \\
\hline 17 & Telaah kurikulum & Diskusi & \multirow{3}{*}{$\begin{array}{l}\text { Vclass, } \\
\text { Zoom, } \\
\text { quizziz, } \\
\text { Youtube }\end{array}$} \\
\hline 18 & Pendidikan Etika dan Kearifan Lokal & Diskusi & \\
\hline 19 & Produksi dan Pemanfaatan Media Pembelajaran & Selainnya & \\
\hline 20 & Biologi Dasar & Diskusi & \multirow{7}{*}{$\begin{array}{l}\text { VClass, } \\
\text { Whatsapp, } \\
\text { quizziz, }\end{array}$} \\
\hline 21 & Evaluasi Pembelajaran & Diskusi & \\
\hline 22 & Pendidikan Etika dan Kearifan lokal & Diskusi & \\
\hline 23 & Strategi Pembelajaran & Diskusi & \\
\hline 24 & Teori Evolusi & Diskusi & \\
\hline 25 & Zoologi Invertebrata & Diskusi & \\
\hline 26 & Zoologi Vertebrata & Diskusi & \\
\hline
\end{tabular}

Pembelajaran menggunakan metode diskusi sebanyak 18 mata kuliah atau $69 \%$. Data ini menjelaskan bahwa metode diskusi merupakan metode yang lazim digunakan oleh pengajar Program Studi Pendidikan Biologi Unila untuk menyampaikan materi pembelajaran.

Diskusi sebagai sebuah keterampilan yang dilatihkan kepada siswa disajikan pada Tabel 3. Penelusuran pustaka menggunakan aplikasi google search dengan kata kunci Keterampilan Diskusi secara online.

Tabel 3. Hasil Tangkapan Layar menggunakan kata kunci Keterampilan Diskusi secara online

\begin{tabular}{|c|c|c|c|c|}
\hline No & Judul Tulisan & Sumber Tulisan & Diskusi & $\begin{array}{l}\text { Keterampilan } \\
\text { Diskusi }\end{array}$ \\
\hline 1 & $\begin{array}{l}\text { Pengaruh Desain E-learning } \\
\text { terhadap Hasil Belajar dan } \\
\text { Keterampilan Berpikir Kreatif } \\
\text { Siswa Dalam Mata Pelajaran } \\
\text { Pemrograman pada Siswa SMK. } \\
\text { (Ni Wayan Nursarita } \\
\text { Prasistayanti, I Wayan Santyasa, } \\
\text { dan I Wayan Sukra Warpala) }\end{array}$ & $\begin{array}{l}\text { Jurnal Teknologi } \\
\text { Pendidikan Vol. 07/02 } \\
\text { Desember 2019. On line } \\
\text { ISSN: 2622-4283, Cetak } \\
\text { ISSN: 2338-9184. } \\
\text { http://doi.org/10.31800/jtp } \\
\text {.kw.v7n2.p138-155 }\end{array}$ & Bukan & Bukan \\
\hline 2 & $\begin{array}{llr}\text { Analisis } & \text { Keterampilan } & \text { Dasar } \\
\text { Mengajar } & \text { Guru } & \text { dalam } \\
\text { Melaksanakan } & \text { Pembelajaran di } \\
\text { Sekolah Dasar. } & \\
\text { (Bastian) } & \end{array}$ & $\begin{array}{l}\text { Jurnal PAJAR (Pendidikan } \\
\text { dan Pengajaran) Volume } 3 \\
\text { No } 62019 . \\
\text { ISSN On line: 2614-1337 } \\
\text { DOI: } \\
\text { http://dx.doi.org/10.33578/ } \\
\text { pjr.v316.7899 }\end{array}$ & Bukan & Bukan \\
\hline 3 & $\begin{array}{l}\text { Peningkatan Keterampilan } \\
\text { Berbicara Melalui Metode } \\
\text { Diskusi Kelompok Model Tanam } \\
\text { Paksa Siswa Kelas X Pemasaran } \\
\text { 1 SMK PGRI 2 Kediri. } \\
\text { (Nur Lailiyah dan Widi } \\
\text { Wulansari) }\end{array}$ & $\begin{array}{l}\text { Jurnal Pendidikan Volume } \\
1 \text { No. } 2 \text { Tahun } 2016 . \\
\text { ISSN: } 2527-6891\end{array}$ & $\mathrm{Ya}$ & $\mathrm{Ya}$ \\
\hline
\end{tabular}




\begin{tabular}{|c|c|c|c|c|}
\hline No & Judul Tulisan & Sumber Tulisan & Diskusi & $\begin{array}{c}\text { Keterampilan } \\
\text { Diskusi }\end{array}$ \\
\hline 4 & $\begin{array}{l}\text { Penerapan Metode Diskusi untuk } \\
\text { Meningkatkan Keterampilan } \\
\text { Berbicara Siswa Kelas XI IPS 1 } \\
\text { SMA Muhammadiyah } \\
\text { Kedawung dalam Pembelajaran } \\
\text { Sejarah. } \\
\text { (Ragil Widya Triana) }\end{array}$ & $\begin{array}{l}\text { 2014. Skripsi. Jurusan } \\
\text { Pendidikan Sejarah. } \\
\text { Universitas Pendidikan } \\
\text { Indonesia. }\end{array}$ & $\mathrm{Ya}$ & $\mathrm{Ya}$ \\
\hline 5 & $\begin{array}{l}\text { Peningkatan } \frac{}{2} \text { Keterampilan } \\
\text { Diskusi Siswa Kelas X SMAN } \\
\text { Pleret, Bantul Melalui Model } \\
\text { Pembelajaran Two Stay Two } \\
\text { Stray. } \\
\text { (Tika Risti Mulawati) }\end{array}$ & $\begin{array}{l}\text { Skripsi. } \\
\text { Program Studi Pendidikan } \\
\text { Bahasa dan Sastra } \\
\text { Indonesia. } \\
2011 .\end{array}$ & $\mathrm{Ya}$ & $\mathrm{Ya}$ \\
\hline 6 & $\begin{array}{l}\text { Keterampilan Membimbing } \\
\text { Diskusi Kelompok Kecil Oleh } \\
\text { Guru Bahasa Indonesia di Kelas } \\
\text { VII SMP Laboratorium } \\
\text { Undiksha. } \\
\text { (Merry Safitri, Gede Gunatama, } \\
\text { Ida Ayu Made Darmayanti) } \\
\end{array}$ & $\begin{array}{l}\text { e-Journal Universitas } \\
\text { Pendidikan Ganesha. Vol. } \\
2 \text { (1) } 2014 . \\
\text { Jurusan Pendidikan } \\
\text { Bahasa dan Sastra } \\
\text { Indonesia. }\end{array}$ & $\mathrm{Ya}$ & $\mathrm{Ya}$ \\
\hline 7 & $\begin{array}{l}\text { The Implemetation of Group } \\
\text { Guidance with Discussion } \\
\text { Technique to Improve Skills of } \\
\text { Interpersonal Conflict Resolution } \\
\text { of XI APK Students SMKN } 1 \\
\text { Sooko Mojokerto. } \\
\text { (Akbari, D.R. dan Nursalim, M). }\end{array}$ & $\begin{array}{l}\text { Program Stusi Bimbingan } \\
\text { Konseling Unesa, } \\
\text { Surabaya. Tanpa tahun. } \\
\text { Tanpa jenis artikel. }\end{array}$ & $\mathrm{Ya}$ & Bukan \\
\hline
\end{tabular}

Data Tabel 3 menunjukkan bahwa diskusi sebagai sebuah keterampilan telah diteliti oleh 4 peneliti dari 7 artikel yang diperoleh dari penelusuran pustaka. Hasil lain yang diperoleh dari teknik pengambilan data ini adalah rubrik penilaian diskusi yang digunakan. Ada 4 artikel yang mengemukakan rubrik penilaian diskusi. Adapun rubrik penilaian meliputi beberapa aspek, yaitu: 1) kekompokan; 2) memotivasi anggota lain; 3) Pengorganisasian kerja kelompok; 4) Inisiatif kerja kelompok; 5) Keaktifan. Skor yang dipakai adalah 1-5, 1 diartikan kurang sekali dan 5 diartikan baik sekali. (Mulawati, 2011: 29-30). Selain itu Mulawati (2011) juga memberikan penilaian diskusi untuk setiap aspek keterampilan diskusi per individu. Aspek tersebut, yaitu: 1) Keberanian/semangat; 2) Kelancaran berbicara; 3) Kejelasan ucapan dan pilihan kata; 4) Penguasaan masalah; 5) Penyampaian pendapat (persetujuan dan sanggahan).

Safitri, Gunatama, dan Ayu (2014) keterampilan diskusi meliputi aspek kegiatan siswa bukan penilaian yaitu 1) memusatkan perhatian; 2) Memperjelas masalah; 3) Menganalisis pandangan siswa; 4) Meningkatkan partisispasi siswa; 5) Menyebarkan kesempatan berpartisipasi; dan 6) menutup diskusi. Lailiyah dan Wulansari (2016), menggunakan rubrik penilaian diskusi yang meliputi, 1) aktivitas berpendapat, aktivitas berbicara, dan kelancaran berbicara.

Rubrik penilaian diskusi jug dikemukakan oleh Triana (2014). Aspek penilaian meliputi, 1) Sumber rujukan; 2) Aktivitas dalam diskusi; dan 3) materi yang didiskusikan. Masing-masing aspek diberi skor 1 sampai 3, yang mana skor 1 tidak sempurna dan skor 3 sempurna.

Hasil survei penilaian diskusi pada Program Studi Pendidikan Biologi meliputi aspek lugas dalam menjawab, argument, dan memberikan pertanyaan, nilai aktivtitas 
mahasiswa, penguasaan materi, menanggapi pertanyaan, kualitas pertanyaan dan jawaban, dan ketepatan materi.

Hasil penelitian memberikan suatu informasi bahwa metode diskusi merupakan suatu cara yang lazim digunakan dalam menyampaikan materi. Selain itu pembelajaran darurat Covid-19 dewasa ini telah menuntut adaptasi berbagai pihak untuk menggunakan wahana pembelajaran online. Wahana pembelajaran online Vclass, Whatsapp, dan lainlain memiliki ciri pembelajaran tertulis. Pembelajaran tertulis yakni pembelajaran yang menggunakan tulisan untuk menyampaikan materi dan menerima materi. Meskipun pembelajaran berproses melalui diskusi maka diskusi yang dilakukan secara tertulis. Pada LMS Vclass terdapat forum diskusi, demikian pula LMS yang dikembangkan oleh Putranto (2012) Perancangan Forum Diskusi Mobile online Learning, yang mana rancangan ini terkoneksi dengan LMS institusi.

Diskusi tertulis menjadi sangat penting sebagai sebuah keterampilan yang harus dimiliki oleh perserta didik dan perlu dibelajarkan. Pegalaman belajar berdiskusi tertulis membutuhkan suatu rambu untuk memudahkan melaksanakan diskusi dan membantu mencapai tujuan pembelajaran. Wulan (2018) menjelaskan bahwa penilaian kinerja tidak hanya dapat menilai keterampilan saja, namun dapat pula untuk menilai sikap, dan pengetahuan. Penjelasan ini dianalogikan bahwa diskusi tertulis yang dinilai menggunakan rubrik penilaian pada Tabel 4 dapat digunakan untuk mengukur keterampilan diskusi, pengetahuan, dan sikap dalam berbahasa.

Tabel 4. Rubrik Pengukuran Keterampilan Diskusi Online Menggunakan Aplikasi WA

\begin{tabular}{|c|c|c|c|}
\hline No & Indikator & Deskriptor & Skor \\
\hline \multirow[t]{3}{*}{1} & Frekuensi Respon & 1) Memberi respon setuju & 0 bila deskriptor tidak tampak \\
\hline & & 2) Memberi respon berupa & 1 bila deskriptor satu tampak \\
\hline & & kalimat & 2 bila bila deskriptor dua tampak \\
\hline \multirow[t]{3}{*}{2} & Kualitas & 1) Penjelasan sederhana atau & 0 bila deskriptor tidak tampak \\
\hline & Percakapan & pada kognitif tingkat rendah & 1 bila deskriptor kesatu tampak. \\
\hline & & $\begin{array}{l}\text { 2) Penjelasan disertai data atau } \\
\text { bukti atau pada kognitif } \\
\text { tingkat tinggi }\end{array}$ & 2 bila deskriptor kedua tampak. \\
\hline \multirow[t]{3}{*}{3} & Sumber kutipan & 1) Tidak menuliskan sumber & 0 bila deskriptor kesatu tampak. \\
\hline & & kutipan & 1 bila deskriptor kedua tampak. \\
\hline & & 2) Menuliskan sumber kutipan & \\
\hline \multirow[t]{3}{*}{4} & Pembukaan & 1) Membuka diskusi & 0 bila deskriptor tidak tampak \\
\hline & $\begin{array}{l}\text { dan } \\
\text { penutupan diskusi }\end{array}$ & 2) Menutup diskusi & $\begin{array}{l}0.5 \text { bila deskriptor satu atau dua } \\
\text { tampak. }\end{array}$ \\
\hline & & & 1 bila kedua deskriptor tampak \\
\hline \multirow[t]{2}{*}{5} & Kesimpulan & 1) Membuat kesimpulan & 0 bila deskriptor tidak tampak \\
\hline & & & 1 bila deskriptor tampak \\
\hline \multirow[t]{3}{*}{6} & Bahasa & 1) Struktur kalimat & 0 bila deskriptor tidak tampak \\
\hline & & (gramatikal) tidak benar & 1 bila deskriptor kesatu tampak. \\
\hline & & $\begin{array}{l}\text { 2) Struktur kalimat } \\
\text { (gramatikal) benar }\end{array}$ & 2 bila deskriptor kedua tampak. \\
\hline $\begin{array}{l}\text { Total } \\
\text { Skor }\end{array}$ & & & 9 \\
\hline
\end{tabular}

(Sumber: Pramudiyanti et al.: 2019) 
Pedoman penilaian keterampilan diskusi disajikan pada Tabel 4. Rubrik penilaian ini tersusun oleh komponen-komponen diskusi yang berjumlah 6 indikator. Rubrik ini memiliki beberapa kelebihan dibandingkan dengan rubrik yang ditemukan. Kelebihan tersebut di antaranya penilaian tidak hanya mencakup kualitas percakapan namun juga memperhatikan struktur bahasa yang digunakan, mengingat bahwa diskusi tertulis menekankan pada maksud kalimat yang tepat dan tidak ambigu (memiliki dua makna atau lebih). Selain itu rubrik ini juga membudayakan untuk melakukan pembukaan dan penutupan diskusi sebagai bentuk kegiatan bersama. Kegiatan bersama yang dimaksudkan di sini yaitu ketika beberapa orang berkumpul untuk membicarakan satu hal maka perlu diawali dengan penyampaian maksud dan tujuan serta menutup kemungkinan para anggota diskusi melakukan pembicaraan tandingan atau tidak relevan. Penutupan diskusi dimaksudkan untuk menyudahai atau mengistirahatkan sementara sebuah diskusi dan juga menjadi tanda bahwa anggota diskusi telah diperkenan untuk berbicara diluar konteks diskusi.

Penggunaan rubrik tersebut meliputi beberapa langkah; 1) membentuk kelompok diskusi atau grup Whatsapp; 2) menjelaskan tatatertib diskusi tertulis sebelum memulai diskusi. Tatatertib meliputi penggunaan simbol-simbol atau emoticon yang disepakati bersama. Ada moderator diskusi, dan lama waktu diskusi. Waktu yang baik untuk diskusi adalah 50 menit dengan anggota 5 orang; 3 ) memulai penilaian diskusi berdasarkan rubrik pada Tabel 4. Contoh diskusi tertulis pada Gambar 1; 4) memberikan umpan balik sesuai capaian pembelajaran yang diharapkan.

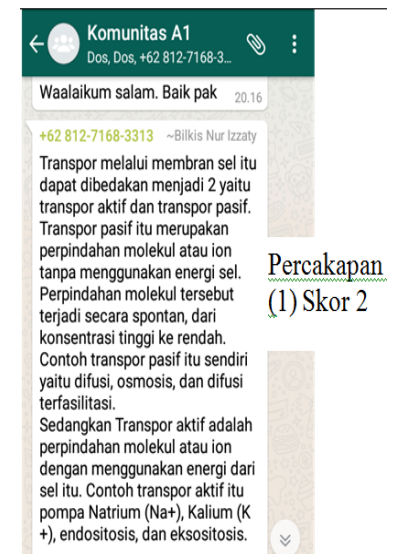

a)

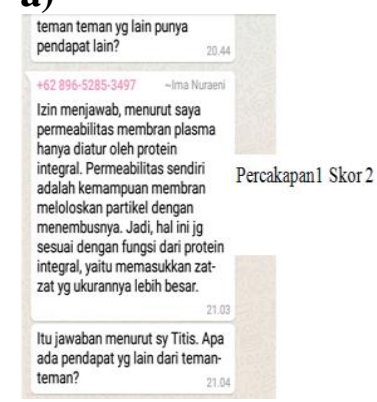

d)

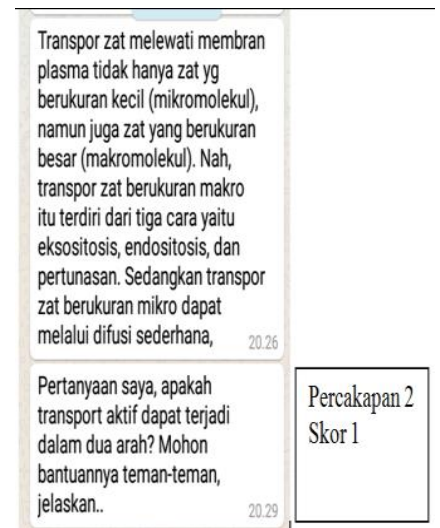

b)

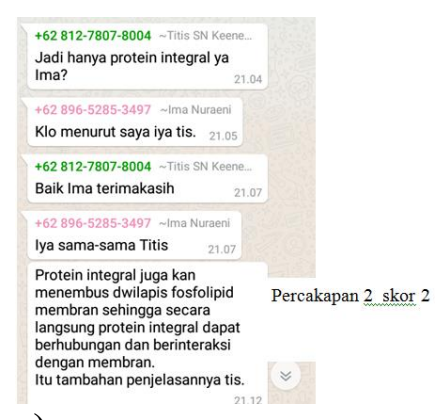

e)

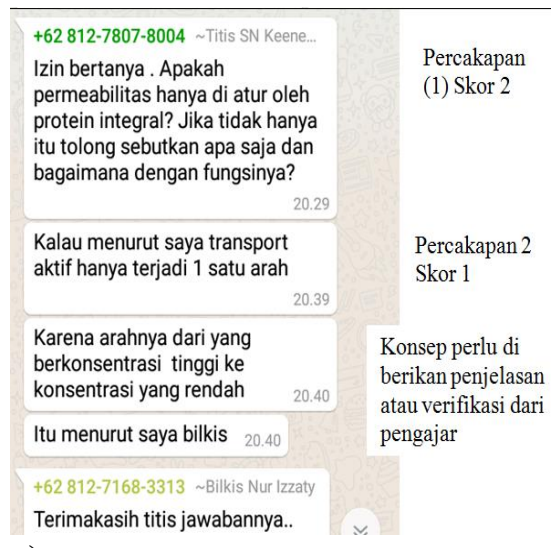

c)

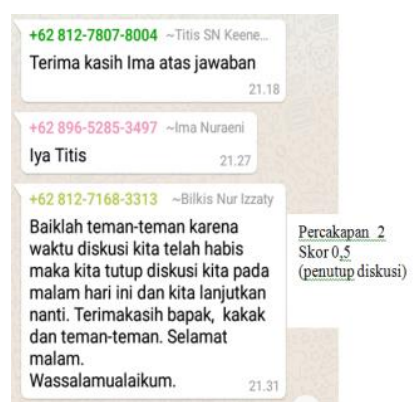

f)

Gambar 1. Contoh diskusi tertulis pada aplikasi whatsapp

Langkah berikutnya untuk menilai percakapan pada Gambar 1. Kita perhatikan terlebih dahulu mahasiswa kita sebut saja Bilkis sebagai moderator, yang mengajukan suatu permasalahan mengenai transpor zat melalui membran sel. Pada bagian awal 
diskusi moderator mengemukakan mengenai transport zat kemudian ada pertanyaan. Berikan penilaian atas pernyataan Bilkis tersebut. Penilaiannya pertama kita lihat dari segi indikatornya yaitu berupa respon, kita berikan skor dua, bila respon berupa kalimat skor 2, kemudian dari segi kualitas percakapan pernyataannya itu pada tingkat kognitif C2 maka skor 1 sementara pertanyaannya:" Apakah transport aktif dapat terjadi dalam dua arah?" Pertanyaan ini adalah pertanyaan C1 maka skornya 1 kemudian muncul pertanyaan juga dari Titis yang bertanya: "Apakah permeabilitas hanya diatur oleh protein integral tidak hanya itu tolong disebutkan apa saja dan bagaimana dengan fungsinya?" Selain pertanyaan tersebut, dia juga menjawab pertanyaan Bilkis, kita beri skor 1. Kemudian juga dia mengemukakan suatu alasannya, dan karena konsep yang dikemukakan salah maka skor 0 . Kemudian aspek bahasa kita perhatikan bahwa kekurangannya ada pada penggunaan huruf, contoh penyingkatan huruf "jg" dan "sy", seharusnya "juga" dan "saya" sementara untuk kalimat yang lain masih dapat diterima sebagai suatu bahasa yang baik kemudian berikutnya adalah pembukaan dan penutupan oleh moderator, Bilkis menutup sehingga dia memperoleh poin 0,5. Pada contoh di atas kita dapat menuliskan data-data dalam tabel seperti berikut.

Tabel 5. Rekapitulasi percakapan diskusi tertulis

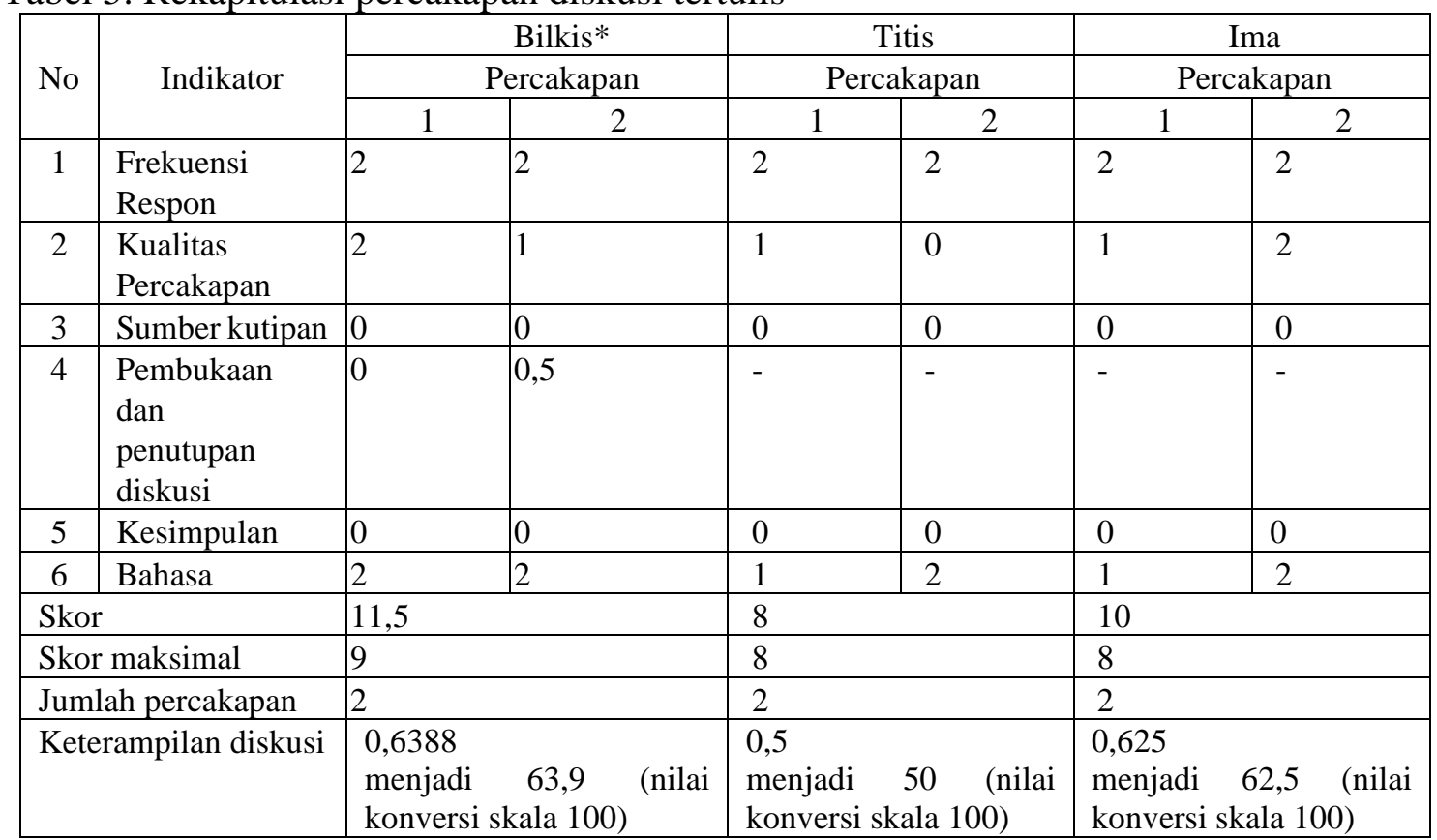

Keterangan:

*moderator

Keterampilan diskusi: skor dibagi jumlah percakapan hasilnya dibagi skor maksimal dikalikan 100.

Penilaian pada Tabel 5 diperoleh informasi bahwa mahasiswa memiliki keterampilan diskusi 63,9. Kelebihan mahasiswa ini ada pada bahasa bila dilihat dari indikator keterampilan diskusi. Selain itu, mahasiswa dengan skor 50 memiliki kelemahan pada kesalahan konsep sehingga diberi nilai nol.

Bobot masing-masing indikator dapat disesuaikan dengan capaian pembelajaran yang diinginkan oleh pengajar. Bobot adalah ukuran kontribusi setiap aspek penilaian terhadap nilai keseluruhan (Wulan, 2018: 68). Kontribusi ini dapat diatur sesuai dengan 
tujuan atau capaian pembelajaran yang diharapkan. Contoh capaian pembelajaran adalah meningkatkan kemampuan pemecahan masalah maka bobot paling tinggi dapat diletakkan pada kesimpulan dan kualitas percakapan. Contoh lain bila capaian pembelajaran adalah pemahaman konsep yang sedang dipelajari maka bobot paling tinggi dapat diletakkan pada kualitas percakapan. Contoh lain bila capaian pembelajaran adalah partisipasi peserta didik dalam proses diskusi maka bobot paling tinggi dapat diletakkan pada frekuensi respon.

Kelemahan penggunaan rubrik ini yakni, perlu kepastian dari pengguna dalam hal batasan frekuensi respon, bentuk respon perlu ditetapkan dan disepakati bersama-sama dengan mahasiswa. Contoh pada kutipan percakapan di atas, permintaan penegasan dari penanya dapat dinilai sebagai respon dan dapat pula tidak, namun pengajar hendaknya membuat kesepakatan terlebih dahulu dengan mahasiswa. Aspek penilaian ini tidak dapat dihilangkan mengingat bahwa peserta diskusi belum semua dapat memberikan kontribusi maksimal. Hal ini berdasarkan pengalaman penelitian dalam melaksanakan diskusi di kelas-kelas. Masih ditemukan beberapa peserta diskusi tidak berpartisipasi dalam diskusi. Ada beberapa kemungkinan pertama mahasiswa masih memiliki rasa malu atau pendiam (Kienhuis dan Chester, 2014:149; King, 2016). Pertimbangan lain adalah ketika pembelajaran berbentuk on line dan mengutamakan teks dalam proses diskusi, contoh pembelajaran virtual menggunakan LMS atau Vclass Unila, maka partisipasi menjadi poin penting untuk mendeteksi keberadaan mahasiswa bersama pengajar saat perkuliahan.

Keterampilan diskusi tertulis merupakan salah satu keterampilan yang penting untuk dibelajarkan kepada mahasiswa atau siswa. Keterampilan ini dapat memberikan manfaat yakni mendidik mahasiswa untuk terlatih menyampaikan pesan tertulis dari segi bahasa, kualitas percakapan maupun kemampuan melatih arus percakapan tertulis. Bagi pengajar rubrik penilaian keterampilan diskusi tertulis dapat menjadi panduan untuk mewujudkan diskusi yang terstruktur dan dapat melatih indikator penilaian diskusi secara bertahap. Tahapan yang dapat dilakukan adalah diawali dengan melatih respon mahasiswa, setelah setiap siswa dapat berpartisipasi maka pada tahap berikutnya yaitu melatih kualitas percakapan, demikian seterusnya. Setiap tahapan dapat dilakukan dalam satu atau tiga pertemuan.

\section{SIMPULAN}

Rubrik keterampilan diskusi tertulis 1) memberikan kemudahan kepada pengajar memberikan penilaian aktivitas belajar mahasiswa; 2) memberikan arah bagi pengajar untuk melatih keterampilan diskusi tertulis bagi mahasiswa; dan 3) memberikan gambaran keterampilan diskusi yang dimiliki oleh mahasiswa.

\section{DAFTAR RUJUKAN}

Cintiasih, T. 2020. Implementasi Model Pembelajaran Daring pada Masa Pandemi Covid-19 di Kelas III SD PTQ Annida Kota Salatiga Tahun Pelajaran 2019/2020. Skripsi. Institut Agama Islam Negeri Salatiga.

Keputusan Menteri Pendidikan dan Kebudayaan No 719. 2020. Pedoman Pelaksanaan Kurikulum Pada Satuan Pendidikan dalam Kondisi Khusus.

Kienhuis, M. and Chester, A. 2014. Interteaching: A Model to Enhance Student Engagement. Halaman 135-154. Curriculum Models for the 21st Century: Using 
Learning Technologies in Higher Education.Editor, Maree Gosper, Dirk Ifenthaler. New York: Springer Science+Business Media.

King, L.B. 2016. Seni Berbicara: kepada siapa saja, kapan saja, di mana saja. Diterjemahkan oleh Marcus Prihminto Widodo. Edisi Revisi Bahasa Indonesia Cetakan ke 19. Gramedia Pustaka Utama. Jakarta.

Lailiyah, N. dan Wulansari, W. 2016. Peningkatan Keterampilan Berbicara Melalui Metode Diskusi Kelompok Model Tanam Paksa Siswa Kelas X Pemasaran 1 SMK PGRI 2 Kediri. Jurnal Pendidikan Volume 1 No. 2 Tahun 2016. ISSN: 2527-6891

Mulawati, T.R. 2011. Peningkatan Keterampilan Diskusi Siswa Kelas X SMAN Pleret, Bantul Melalui Model Pembelajaran Two Stay Two Stray.Skripsi. Program Studi Pendidikan Bahasa dan Sastra Indonesia.Universitas Negeri Yogyakarta.

Pramudiyanti, dkk. 2019. Learning writing discussion skills via Whatsapp using Structured and Unstructured Discussion Techniques. Proceeding of International Conference on Islamic Education: Challenges in Technology and Literacy. Faculty of Education and Teacher Training, Universitas Islam Negeri Maulana Malik Ibrahim Malang. November 6-7, 2019. P-ISSN: 2477-3638, E-ISSN: 2613-9804. Volume: 4.

Putranto, A. Perancangan Forum Diskusi Mobile On Line Learning. Comtech. Vol.3 No.2 Desember 2012: 860-871.

Safitri, M. Gunatama, G. Darmayanti, I.A.M. 2014. Keterampilan Membimbing Diskusi Kelompok Kecil Oleh Guru Bahasa Indonesia di Kelas VII SMP Laboratorium Undiksha. e-Journal Universitas Pendidikan Ganesha. Vol. 2 (1) 2014.

Triana, R.W. 2014. Penerapan Metode Diskusi untuk Meningkatkan Keterampilan Berbicara Siswa Kelas XI IPS 1 SMA Muhammadiyah Kedawung dalam Pembelajaran Sejarah. Skripsi. Jurusan Pendidikan Sejarah. Universitas Pendidikan Indonesia.

Waruwu, M. 2020. Studi Evaluatif Implementasi Pembelajaran Daring Selama Pandemi Covid-19. Jurnal Administrasi Pendidikan. Vol. 27 issue 2. Oktober. Hal 288-295. DOI: https://doi.org/10.17509/jap.v27i2. ISSN: p.1412-8152e.2580-1007.

Wulan. A.R. 2018. Menggunakan Asesmen Kinerja untuk Pembelajaran Sains dan Penelitian. Bandung: UPI Press.

Yuberti. 2015. Online Group Discussion Pada Mata Kuliah Teknologi Pembelajaran Fisika. Jurnal Ilmiah Pendidikan Fisika "Al-Biruni". Vol. 04(02) halaman 145153. 